\title{
УДОСКОНАЛЕННЯ ЯКОСТІ ПІДГОТОВКИ ЛІКАРІВ В УМОВАХ БОЛОНСЬКОГО ПРОЦЕСУ
}

\author{
Л. В. Глушко, Н. В. Чаплинська, Н. З. Позур, Т. Ю. Гавриш \\ ДВНЗ “Івано-Франківський наиіональниймедичний університет”
}

\section{IMPROVING THE QUALITY OF DOCTORS' TRAINING IN THE BOLOGNA PROCESS}

\author{
L. V. Hlushko, N. V. Chaplynska, N. Z. Pozur, T. Yu. Havrysh \\ SHEI "Ivano-Frankivsk National Medical University"
}

\begin{abstract}
У статті розглядається актуальність підвищення якості підготовки лікарів за кредитно-модульною системою організації навчального процесу та з врахуванням можливостей і соціально-медичних потреб українського сьогодення. Відповідно до освітньо-кваліфікаційної характеристики запропоновано педагогічний підхід у викладанні клінічних дисциплін, скерований на практичну професійно-орієнтовану роботу студентів.
\end{abstract}

The article adduces the relevance of improving the quality of physicians training in terms of credit-modular system of educational process taking into account the opportunities and socio-medical requirements of Ukrainian today. According to the educational qualification characteristics it was proposed a pedagogical approach in teaching of clinical courses, aiming at the practical professionally-oriented work of students.

Вступ. Процеси глобалізації сьогодення зумовлюють новітні тенденції в освіті, що $€$ необхідною передумовою подальшого ії розвитку й удосконалення. Адже досягти нових результатів у вищій освіті, створити якісну систему підготовки фахівців і на цій основі забезпечити конкурентоспроможність випускників та престиж української вищої освіти у світовому просторі можна лише за умов упровадження нових технологій навчання $[1,3,5]$.

Медична освіта України - органічна складова національної вищої освіти, яка переживає період оновлення і системної реорганізації. В останнє десятиріччя процес професійної підготовки лікаря в Україні відбувається під впливом вимог європейського освітнього простору. Це пов'язано з впровадженням у вищій медичній школі основних положень Болонської системи, необхідністю надати майбутньому лікарю уніфіковані для різних країн професійні знання й навички. Рівень оволодіння ними повинен відображатися в дипломі, що $є$ перепусткою до професійної реалізації особистості в будь-якій державі $[2,4]$.

Основна частина. Проведення реформ у галузі вищої медичної освіти потребує обгрунтованих, продуманих рішень на основі синтезу наукових і практичних досягнень національного та світового масштабу. Важливим є раціональне використання досвіду фахівців

(сЛ. В. Глушко, Н. В. Чаплинська, Н. 3. Позур, Т. Ю. Гавриш зарубіжних вищих медичних навчальних закладів. Так, у стінах Івано-Франківського державного медичного університету був проведений Всеукраїнський симпозіум на тему: “Кредитно-модульний принцип організації навчального процесу у вищих медичних закладах України III-IV рівнів акредитації: стан, проблеми, перспективи" з участю спеціалістів медичного факультету Мюнхенського університету імені Людвіга Максиміліана, які поділились своїм досвідом впровадження Болонської системи у навчальний процес їхнього вузу.

За умови відсутності цілісного комплексу нормативних документів МОН України 3 питань кредитно-модульної системи організації навчального процесу (КМСОНП) в ДВНЗ “Івано-Франківський національний медичний університет" розроблено Тимчасове положення про КМСОНП, яке регламентує педагогічну діяльність університету. Згідно з цим Положенням, у 2005 році навчання на засадах ECTS запроваджено на першому курсі за спеціальністю “Лікувальна справа". У 2010-2011 навчальному році на кафедрі терапії та сімейної медицини факультету післядипломної освіти вперше розпочато викладання циклу “ЗЗагальна практика-сімейна медицина” для студентів 6 курсу за Болонською системою.

Однією з ключових позицій, за якою ведеться викладання, $є$ така якість педагогічного процесу, де на кожному його етапі наявний зворотний зв'язок зі сту- 
дентом. Це дозволяє підсилити мотивацію до навчально-пізнавального процесу, психологічно розвантажити студента, створюючи здорову конкуренцію в освоєнні навчального матеріалу. Сьогодні вважається не настільки важливим дати конкретний матеріал (фактичні дані можна знайти в багатьох інформаційних джерелах), як розвивати особистість медика у системі дисципліни. Відомо, що Всесвітня організація охорони здоров'я (BOO3) запровадила таке визначення сучасного висококваліфікованого лікаря як особи, що “надає допомогу, приймає рішення, спілкується, керує та враховує інтереси й потреби суспільства" [2].

Нові знання на 6 курсі легко сприйматимуться студентами на підставі наявності у них хорошої бази 3 фундаментальних і клінічних дисциплін, закладеної на попередніх курсах. Однак тут викладачі кафедри терапії та сімейної медицини факультету післядипломної освіти зустрілися з деякими труднощами. Як відомо, при щоденному оцінюванні знань студентів при КМСОНП перевагу надають стандартизованим методам: тестуванню, структурованим письмовим роботам, усному опитуванню, контролю практичних навичок. Використання тестів у навчальному процесі надійно увійшло в світову педагогічну практику. Постійно розвиваються наші уявлення про призначення та педагогічні можливості тестів, їх форми та формати запитань. Проте доволі часте використання такої форми контролю поступово почало відтісняти на другий план найбільш важливу частину заняття 3 клінічних дисциплін - практичну професійно-орієнтовану роботу студентів. Як результат, студент, котрий добре справляється 3 вирішенням тестових завдань, не завжди може пояснити та обгрунтувати свою відповідь. Його знання є фрагментарними, базуються на стандартних тренажерах-моделях ситуацій, що неодноразово повторюються, а клінічного мислення та практичної підготовки бракує.

Без сумніву, тестування більше, ніж інші методи вимірювання знань, які використовуються у сучасній педагогіці, відповідає критеріям якості при визначенні рівня теоретичної підготовки. Однак сучасний професійний медичний працівник повинен володіти не лише теоретичними знаннями, але й високоточними відпрацьованими практичними навичками, швидко приймати правильні рішення в умовах стресу та дефіциту часу. Єдиним ефективним способом для до- сягнення таких цілей $є$ робота безпосередньо з пацієнтами. 3 метою збільшення мотивації студентів до засвоєння ними такого матеріалу доцільним вважаємо перерозподіл кількості балів під час оцінювання успішності навчання на клінічних дисциплінах на користь практичних навиків. Пропонуємо різко збільшити відсоток часу навчального процесу для освоєння студентами навичок із надання невідкладної медичної допомоги безпосередньо в лікарських амбулаторіях загальної практики-сімейної медицини, інших клінічних базах кафедр. Лише біля ліжка хворого, збираючи скарги та анамнез, виконуючи фізикальне обстеження, аналізуючи результати додаткових методів дослідження, студент 6 курсу зможе самостійно інтегрувати знання 3 предметів, вивчених на попередніх курсах.

У такому процесі навчання дуже важливою є роль викладача, його компетентності, сумлінності, працездатності. Для того, щоб навчання студента було ефективним, а майбутня оцінка об'єктивною, викладач повинен простежити за етапом визначення діагнозу, вибору та обгрунтування найефективнішої лікувальної тактики, надати додаткову інформацію для порівняння, відібрати патології для диференційної діагностики. Тільки педагог із великим стажем лікаря може дати своїм учням-студентам таку інформацію, якої вони не знайдуть у жодній книжці.

Запропонований педагогічний підхід у викладанні клінічних дисциплін, особливо на 6 курсі, спонукатиме до вмілого оперативного і свідомого використання засвоєних знань, буде сприяти їх закріпленню в нових умовах справжньої, а не тестової клінічної ситуації. А це, в остаточному підсумку, допоможе майбутнім лікарям зрозуміти й оцінити затребуваність теоретичних фундаментальних знань.

Висновки. Цілком логічним є висновок про необхідність серйозної підготовки і студентів, і викладачів вищих медичних навчальних закладів України. У складний період освітніх інтеграційних процесів доцільним було б максимально зберегти позитивні здобутки національної системи медичної освіти 3 врахуванням можливостей і соціально-медичних потреб українського сьогодення, а також ефективно використати досвід європейських країн для підготовки мобільного, творчого, конкурентоспроможного лікаря високої кваліфікації. 


\section{Лiтература}

1. Калюжна Н. Л. Приєднання України до Болонської конвенції, ії переваги та недоліки [Електронний ресурс]. - Режим доступу до статті : http://www.rusnauka.com/ 1_NIO_2008/Pedagogica/25782.doc.htm.

2. Неловкіна Берналь О. А. Соціально-професійна підготовка сучасного лікаря : американський та європейський підходи / О. А. Неловкіна Берналь // Соціальна педагогіка : теорія та практика. -2010. - № 1.-С. 101-106.

3. Пикалюк В. С. Болонський процес в медвузах через п’ять років після старту : на що сподівались (що планували) і що маємо [Електронний ресурс]. - Режим доступу до

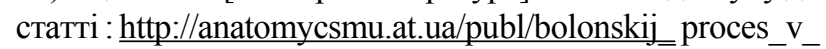

medvuzakh_cherez_p_jat_rokiv_pislja_startu_na_shho_ spodivalis_shho_planuvali_i_shho_maemo/1-1-0-5.

4. Радомська Л. А. Українська система вищої освіти : переваги й недоліки Болонського процесу [Електронний peсурс]. - Режим доступу до статті : http:// conf.vstu.vinnica.ua/humed/2010/txt/Radomska_Stadniy.php.

5. Міцність знань студентів - невід'ємна умова успішності подальшої професійної діяльності / М. І. Тарапата, П. Я. Кравцов, Б. Г. Попов [та ін.] // Матеріали науковопрактичної конференції “Самостійна робота студентів вищих навчальних закладів : досвід, проблеми та перспективи", 20-21 квітня 2004 р. - Харків, 2004. - С. 147-148. 